\title{
FORMULASI CREAM ANTIMIKROBA DARI EKSTRAK KULIT PISANG AGUNG SEMERU DAN PISANG MAS KIRANA VARIETAS LUMAJANG
}

\author{
Dwi Nur Rikhma Sari ${ }^{1 *}$, David Kristian Susilo ${ }^{2}$, Siti Zainiyatus Zakiya ${ }^{3}$, Washila Khoiriyah ${ }^{4}$, Siti Nur \\ Kholifah $^{5}$ \\ 1,3,4,5 Program Studi Pendidikan Biologi Fakultas Pendidikan MIPA \\ ${ }^{2}$ Program Studi Pendidikan Ekonomi Fakultas Pendidikan Ilmu Sosial IKIP PGRI Jember, Jawa Timur \\ Indonesia
}

*E-mail: rikhmasari.dnrs@gmail.com

\begin{abstract}
This research was to know the quality of antimicrobial cream from banana's peel extract of Agung Semeru and Mas Kirana. This research is descriptive qualitative by using banana's peel extract of Agung Semeru and Mas Kirana at concentration 100\%. The parameters of this research are organoleptic test and homogeneity test and $\mathrm{pH}$ and absorption and stickiness and power spread and color intensity and smell of cream. The results of antimicrobial cream from banana's peel extract of Agung Semeru and Mas Kirana and the combination of both in homogeneity test did not occur agglomeration. This antimicrobial cream have pH ranged from 5-6 and still safe for skin and have the absorption requirement more $1 \mathrm{mg} / 1 \mathrm{ml}$ and have power spread and fulfill the physically tested covers.
\end{abstract}

Keywords: Cream; Banana peel extract; Agung Semeru; Mas Kirana.

\section{PENDAHULUAN}

Kulit pisang pisang Agung Semeru dan pisang Mas Kirana merupakan salah satu penghasil limbah buah pisang di Kabupaten Lumajang dan sebagian besar masyarakat masih menganggap kulit pisang sebagai limbah organik sehinga hanya dimanfaatkan sebagai bahan pakan ternak (Susanti, 2006). Berdasarkan hasil penelitian uji fitokimia ekstrak kulit pisang Mas Kirana varietas Lumajang mengandung senyawa antimikroba yaitu fenol, saponin dan terpen, sedangkan pada ekstrak kulit pisang Agung Semeru varietas Lumajang mengandung senyawa antimikroba berupa fenol, terpen, saponin dan alkaloid (Sari dan Susilo, 2017).

Disisi lain, kulit merupakan lapisan terluar dari tubuh yang berfungsi sebagai barier dari berbagai infeksi mikroorganisme penyebab penyakit kulit antara lain Staphylococcus aureus (Rosalina, dkk., 2010), Pseudomonas aeruginosa (Radji, 2011) dan beberapa kelompok dari fungi/jamur seperti Candida albicans (Jawetz, 2005). Selama ini, pengobatan penyakit infeksi kulit oleh mikroba masih menggunakan obat topikal yang terbukti lebih efektif cepat dalam membunuh mikroorganisme patogen tersebut, tetapi jika digunakan dalam jangka waktu lama dapat menyebabkan mikroba mengalami resistensi terhadap obat (Jawetz, 2005). Berdasarkan hal terebut, perlu dilakukan alternatif lain dalam mencegah resistensi mikroba patogen terhadap obat, salah satunya dengan menggunakan obat herbal, salah satunya dengan pembuatan cream kulit berbahan baku ekstrak kulit pisang Agung Semeru dan Mas Kirana yang telah terbukti mengandung senyawa antimikroba.

Cream kulit merupakan sediaan setengah padat yang hanya mengandung air kurang dari $60 \%$ serta hanya digunakan sebagai obat luar. Cream kulit memiliki sifat yang umum yaitu melekat pada permukaan tempat pemakaian dalam waktu yang relatif lama, memberikan efek yang mengkilap, berminyak, bersifat melembabkan kulit, memiliki daya sebar merata, mudah mengalami penetrasi pada kulit, serta mudah/sulit diusap atau dicuci (Anwar, 2012). Selain itu cream kulit memiliki kemampuan untuk menyebar dengan sangat baik pada kulit dan tidak menyebabkan terjadinya penyumbatan pada kulit, praktis, mudah dibersihkan serta merupakan sediaan farmasi yang digunakan secara topikal dalam pengobatan berbagai penyakit kulit (Setyowati, et al., 2013).

Pada penelitian ini, bentuk sediaan yang dipilih yaitu bentuk cream emulsi minyak dalam air dikarenakan memiliki penyebaran yang merata dan mudah dibersihkan. Tujuan dilakukan penelitian ini adalah menciptakan bentuk sediaan cream kulit dengan bahan dasar dari alam yakni kulit buah pisang Agung Semeru dan Mas Kirana untuk 
pembuatan obat antimikroba topikal dari ekstrak kulit buah pisang Agung Semeru dan Mas Kirana.

\section{METODOLOGI PENELITIAN}

Penelitian ini dilakukan pada bulan Oktober 2017 di Laboratorium Biologi FP. MIPA IKIP PGRI Jember serta Laboratorium Fakultas Biologi Universitas Jember. Jenis penelitian ini adalah penelitian deskriptif kualitatif.

\section{a. Alat dan Bahan}

Alat yang akan digunakan pada penelitian ini yaitu alat gelas, batang pengaduk, kapas, evaporator, mortar dan penggerus mortar, water bath, cawan petri, pipet volume, gelas beaker 25 $\mathrm{mL}$, Penggaris, pengaduk, wadah cream, $\mathrm{pH}$ meter, kertas saring, sendok tanduk dan timbangan analitik. Sedangkan bahan yang digunakan pada ekstrak kulit pisang Agung Semeru dan pisang Mas Kirana, kertas saring, etanol 95\%, akuades, cera flava, nipasol, nipagin, olium olividae, olium buble gum, olium jill platinum dan olium vanilla peach (sebagai aroma cream kulit).

\section{b. Pembuatan Simplisia Ekstrak Kulit Pisang}

Pembuatan simplisia kulit pisang Agung Semeru dan pisang Mas Kirana pada penelitian ini dilakukan dengan beberapa tahapan yaitu pengumpulan kulit buah pisang, sortasi basah, perajangan kecil-kecil, pengeringan dan sortasi kering menghasilkan simplisia kering dan simplisia basah. Untuk membuat ekstraksi kulit pisang sebagai berikut: Membersihkan kulit pisang Agung Semeru sehingga tidak terdapat kotoran yang menempel kemudian mengirisnya menjadi kecil-kecil. Setelah itu dikering-anginkan hingga kulit pisang tersebut kering. Selanjutnya, kulit pisang Agung yang sudah kering, dimasukkan ke dalam diblender hingga halus kemudian dimaserasi. Sebanyak 100 gram kulit pisang Agung Semeru yang telah dihaluskan dimaserasi dengan $300 \mathrm{ml}$ air selama 1 X 24 jam. Ekstrak yang diperoleh disaring dengan corong Buchner menggunakan vakum dan filtrat yang diperoleh diuapkan dengan rotary vacuum evaporator hingga didapat ekstrak kental. Agar diperoleh ekstrak kulit pisang dalam jumlah banyak proses ekstraksi dilakukan sebanyak enam kali. Pada penelitian ini menggunakan ekstrak kulit pisang Agung Semeru, Mas Kirana dan kombinasi keduanya pada konsentrasi $100 \%$, berdasarkan pada hasil penelitian sebelumnya bahwa konsentrasi $100 \%$ menunjukkan hasil yang optimal dalam menghambat pertumbuhan mikroorganisme penyakit kulit.

\section{c. Pembuatan Cream Kulit}

Menimbang masing-masing komposisi bahan yang akan digunakan, selanjutnya memisahkan dua komponen bahan. Pembuatan fasa air dengan cara mencampurkan bahan-bahan pembuat fasa air pada wadah berupa cawan proselen 1 dilengkapi dengan pengaduk yang terdiri dari bahan Ekstrak, Nipagin, dan Nipasol yang selanjutnya dilakukan pengadukan sampai homogen. Pembuatan fasa minyak dilakukan dengan mencampurkan bahan pembuat fasa minyak yaitu Cerra yang sebelumnya telah diencerkan diatas magentik stirer, dan memasukkan Olium Alivae secara sedikit demi sedikit sesuai dengan takarannya, selanjutnya dilarutkan dan diaduk sampai benar benar homogen. Setalah semua homogen, langkah selanjutnya mencampurkan kedua fasa tersebut dengan cara menambahkan fasa minyak sedikit demi sedikit ke dalam fasa air sambil dilakukan pengadukan sampai semua komponen teraduk sempurna dan homogen. Selanjutnya setelah cream benar benar homogen, memberikan aroma pewangi yang sesuai dengan yang diinginkan, pada penelitian ini menggunakan aroma bubble gum, jilo platinum dan vaniila peach.

\section{d. Pengujian Sediaan Cream \\ Pengujian Sediaan Cream}

Pengujian sediaan cream kulit yang telah dibuat, dilakukan pengujian terhadap sediaan cream tersebut, meliputi:

1. Uji organoleptik. Diamati bentuk cream, warna dan bau cream. Ini dilakukan untuk mengetahui cream yang dibuat sesuai dengan warna dan bau ekstrak yang digunakan. Cream yang baik memiliki konsistensi setengah padat (Ansel, 1989)

2. Uji homogenitas. Diambil 1 gram cream kulit pisang Agung Semeru dan Mas Kirana pada bagian atas, tengah, dan bawah kemudian dioleskan pada sekeping kaca transparan. Diamati jika terjadi pemisahan fase. sediaan cream harus menunjukkan susunan yang homogen dan tidak terlihat adanya butiran kasar. [Ditjen POM, 1985]

3. Uji $\mathrm{pH}$. Ditimbang sebanyak 1 gram ekstrak cream lamun dan diencerkan dengan $10 \mathrm{ml}$ aquades. Kemudian gunakan $\mathrm{pH}$-meter yang bagian sensornya dan dibaca $\mathrm{pH}$ pada bagian monitor.

4. Uji daya serap. Ditimbang cream ekstrak daun lamun sebanyak 1 gram, kemudian ditetesi air sambil diaduk atau dikocok. penetesan air pada cream dlakukan sampai tidak dapat menyerap air lagi atau cream memisah dengan air. Kemudian dihitung jumlah air yang dibutuhkan hinggga cream memisah.

5. Pengujian Daya Lekat : Sampel 0,25 gram diletakkan diantara 2 gelas objek pada alat uji daya lekat, kemudian ditekan beban $1 \mathrm{~kg}$ 
selama 5 menit, beban diangkat dan diberi beban 80 gram pada alat dan dicatat waktu peleasan gel (Miranti, 2009).

6. Pengujian Daya Sebar : Menimbang 0,5 gram sampel cream diletakkan di atas kaca bulat berdiameter $15 \mathrm{~cm}$, kaca lainnya diletakkan di atasnya dan dibiarkan selama 1 menit. Diameter penyebaran cream diukur. Setelahnya, ditambahkan 50 gram, 100 gram , dan 150 gram beban tambahan dan didiamkan selama 1 menit lalu diukur diameter yang konstan. Semakin lebar diameternya, maka semakin baik penyebaran creamnya. Selanjutnya dibuat grafik antara beban vs luas sebaran cream (Astuti et al., 2010).

\section{HASIL DAN PEMBAHASAN}

Penelitian ini, merupakan penelitian deskriptif yang melakukan pengujian dan pengamatan terhadap hasil sediaan cream kulit ekstrak kulit pisang Agung Semeru, Mas Kirana dan kombinasi keduanya, meliputi pengujian organoleptik. $\mathrm{pH}$, daya sebar, daya serap, daya lekat serta uji homogenitas sediaan cream (tabel 1).

Tabel 1. Uji sediaan cream kulit Esktrak Kulit Pisang Agung Semeru, Mas Kirana

\begin{tabular}{clccc}
\hline Kriteria Uji & \multicolumn{1}{c}{ Keterangan } & $\begin{array}{c}\text { Mas Kirana } \\
(\mathbf{M K}) \mathbf{1 0 0} \%\end{array}$ & $\begin{array}{c}\text { Agung Semeru } \\
(\mathbf{A S}) \mathbf{1 0 0 \%}\end{array}$ & $\begin{array}{c}\text { Kombinasi Pisang } \\
\text { AS }-\mathbf{M K} \mathbf{1 0 0 \%}\end{array}$ \\
\hline & Cera Flava & $27,24 \mathrm{~g}$ & $27,24 \mathrm{~g}$ & $27,24 \mathrm{~g}$ \\
& Nipasol & $0,15 \mathrm{~g}$ & $0,15 \mathrm{~g}$ & $0,15 \mathrm{~g}$ \\
Fromulasi krim & Nipagin & $0,05 \mathrm{~g}$ & $0,05 \mathrm{~g}$ & $0,05 \mathrm{~g}$ \\
Komposisi Bahan & Olium Olividae & $63,5 \mathrm{~g}$ & $63,5 \mathrm{~g}$ & $63,5 \mathrm{~g}$ \\
& Olium Buble Gum & 4 tetes & 4 tetes & 4 tetes \\
Uji pH Krim & Ekstrak Krim Jadi & 5.9 & 6.6 & 6.7 \\
Uji Daya Serap (g/mL) & Ekstrak Krim Jadi & 5,5 & 4,3 & 4 \\
Uji Daya Sebar (cm) & Ekstrak Krim Jadi & 2.5 & 2.9 & 2 \\
Uji Daya Lekat (second) & Ekstrak Krim Jadi & 0.27 & 00.32 & 00.31 \\
Uji Homogenitas & Ekstrak Krim Jadi & Homogen & Homogen & Homogen \\
Intensitas Warna & Ekstrak Krim Jadi & Cream tua & Cream muda Soft & Cream agak muda \\
Aroma/bau & Ekstrak Krim Jadi & Vanilla Prach & Bubble Gum & Jilo Platinum \\
\hline
\end{tabular}

Pengujian Uji organoleptis dilakukan untuk melihat bentuk fisik cream kulit yang telah dibuat meliputi bentuk, warna dan bau/ berdasarkan hasil yang didapat bentuk sediaan yang diperoleh berupa setengah padat, warna secara keseluruhan untuk semua ekstrak adalah cokelat cream (Gambar 1 dan 2) dengan warna bau yang khas adalah bau kulit pisang meskipun bau nya tidak tajam atau menyengat. Namun pada penelitian ini, peneliti memberikan aroma pada masing-masing sediaan cream yang telah dibuat yaitu aroma buble gum (Pisang Agung Semeru), jilo platinum (Kombinasi Pisang) dan vanilla peach (pisang Mas Kirana). Aroma atau bau dan warna yang dihasilkan cream ekstrak kulit pisang tergantung dari konsentrasi cream yang digunakan.

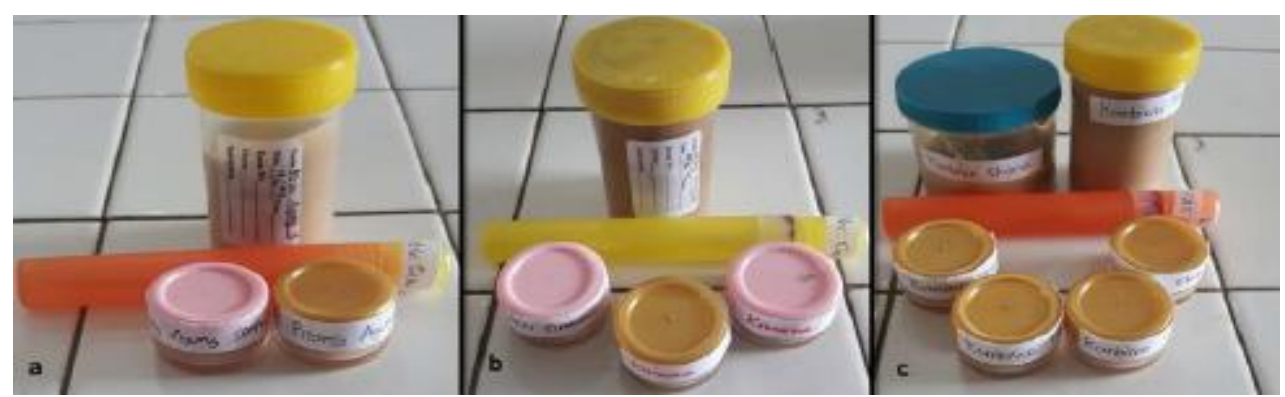

Gambar 1. Sediaan Cream Ekstrak Kulit Pisang a)Agung Semeru dan b) Mas Kirana c)Kombinasi

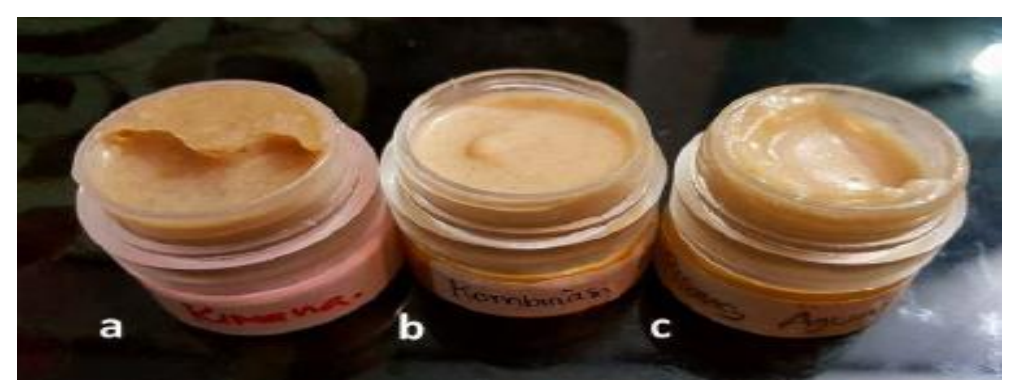

Gambar 2. Tekstur Cream Ekstrak Kulit Pisang a)Agung Semeru dan b) Mas Kirana c)Kombinasi 


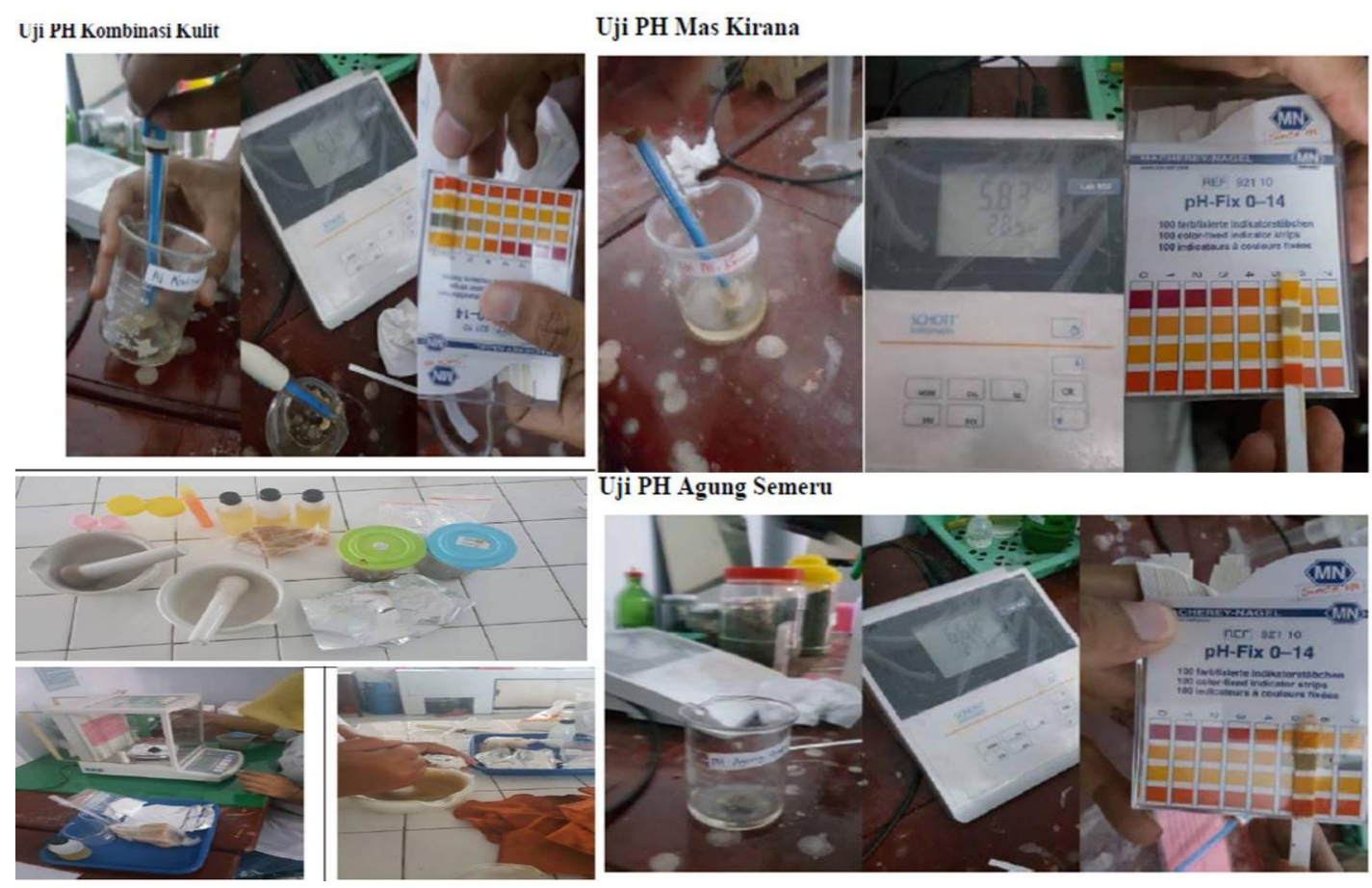

Gambar 3. Salah Satu Uji Organoleptik, pH yaitu: a)Agung Semeru dan b) Mas Kirana

Pada penelitian in, menggunakan ekstrak kulit pisang dengan perlakuan $100 \%$ untuk masing-masing ekstrak, dikarenakan berdasarkan hasil penelitian yang telah dilakukan sebelumnya bahwa konsentrasi $100 \%$ merupakan konsentrasi terbaik untuk menghambat pertumbuhan mikrorganisme penyebab penyakit infeksi pada kulit. Selain itu, semakin tinggi konsentrasi ekstrak aroma maka semakin meningkat (Juwita, et al., 2013) dan warna cream menjadi creak kecokelatan.

Pengujian homogenitas dilakukan untuk mengetahui apakah bahan-bahan sediaan cream yang telah dibuat telah tercampur dengan sempurna yang ditandai dengan tidak adanya gumpalan-gumpalan sisa ekstraksi kulit pisang. Hasil penelitian ini menunjukkan bahwa untuk semua sediaan cream yang telah dibuat baik dari ekstrak kulit pisang Agung Semeru, Mas Kirana dan kombinasi keduanya menunjukkan hasil yang homogen dimana tidak terdapat gumpalan. Hal ini, dikarenakan terdapat senyawa flavonoid pada esktrak kulit pisang pada penelitian ini yang menyebabkan ekstrak dapat bercampur dengan basis $\mathrm{A} / \mathrm{M}$ sehingga tidak terjadi penggumpalan atau pemisahan fase. Hal ini sesuai dengan penelitian pada uji fitokimia ekstrak kulit ekstrak kulit pisang Agung Semeru dan kulit pisang Mas Kirana menunjukkan senyawa antimikroba termasuk senyawa flavonoid (Sari dan Susilo, 2017).

Uji pengujian $\mathrm{pH}$ (Gambar 3) pada sediaan cream kulit pada penelitian ini bertujuan mengetahui keamanan sediaan cream saat digunakan sehingga tidak mengiritasi kulit. Hasil $\mathrm{pH}$ cream ekstrak kulit pisang Agung Semeru, Mas Kirana dan kombinasi keduanya berkisar 5-6 (tabel 1). Perbedaan nilai $\mathrm{pH}$ pada sediaan cream kulit pisang ini tidak terlalu memberikan oengaruh, selama nilai $\mathrm{pH}$ masih pada batas 4,5 - 6,5 (Tranggono dan latifah, 2007). Pengujian daya serap sediaan cream kulit ekstrak kulit pisang Agung Semeru, Mas Kirana dan kombinasi keduanya bertujuan untuk mengetahui kemampuan cream dalam menyerap air dimana cream maksimal jika cream sudah tidak mampu menyerap air lagi. Hasil uji daya serap pada penelitian ini memiliki daya serap berkisar 4-5,5 $\mathrm{mL}$ (tabel 1), dimana syarat uji daya serap pada kulit harus mempunyai kelarutan yang sesuai dalam mineral dan air dengan kadar lebih dari 1 $\mathrm{mg}$ cream dapat larut dalam $1 \mathrm{mg}$ air (Juwita, et al., 2013), dan sediaan cream pada penelitian ini telah memenuhi syarat uji daya serap karena > $1 \mathrm{mg} / 1 \mathrm{~mL}$ air.

Pengujian daya sebar sediaan cream kulit ekstrak kulit pisang Agung Semeru, Mas Kirana dan kombinasi keduanya bertujuan untuk mengetahui kelunakkan sediaan cream saat dioleskan pada permukaan kulit. Hasil uji daya sebar pada penelitian ini menghasilkan daya sebar yang besar yakni berkisar pada $2 \mathrm{~cm}-2,9 \mathrm{~cm}$ (tabel 1). Berdasarkan hasil uji daya sebar Sediaan cream yang sesuai adalah sediaan cream kulit ekstrak kulit pisang Agung Semeru, Mas Kirana dan kombinasi keduanya menunjukkan 
kemampuan menyebar saat dioleskan. Hal ini sesuai dengan pendapat bahwa cream yang baik yaitu cream yang diberikan beban semakin besar maka daya sebar krimnya semakin lebar (Garg et al., 2002) serta jika dioleskan akan menyebar, berati cream tipe A/M mudah dioleskan.

\section{KESIMPULAN}

Sediaan cream kulit ekstrak kulit pisang Agung Semeru, Mas Kirana dan kombinasi keduanya pada penelitian ini dengan konsentrasi $100 \%$ pada uji homogenitas tidak terjadi penggumpalan, $\mathrm{pH}$ berkisar 5-6 dan masih aman untuk kulit, memiliki sediaan cream yang memenuhi persyaratan daya serap yakni lebih 1 $\mathrm{mg} / 1 \mathrm{ml}$. Uji daya sebar cream A/M mudah dioleskan sehingga cream ekstrak sediaan cream kulit ekstrak kulit pisang Agung Semeru, Mas Kirana dan kombinasi memenuhi uji daya sebar.

\section{DAFTAR PUSTAKA}

[1] Ansel. 1989. Pengantar Bentuk Sediaan Farmasi. UI Press. Jakarta.

[2] Anwar, Effionora. 2012. Eksipien dalam Sediaan Farmasi (Karakterisasi dan Aplikasi). Dian Rakyat : Jakarta

[3] Astuti I. Y., D. Hartanti, dan A. Aminiati, 2010, Peningkatan Aktivitas Antijamur Candidia albicans Salep Minyak Atsiri Daun Sirih (Piper bettle LINN.) melalui Pembentukan Kompleks Inklusi dengan $\beta$ siklodekstrin, Majalah Obat Tradisional,15: 94- 99 .

[4] Ditjen POM. 1985. Formularium Kosmetika Indonesia. Departemen Kesehatan Republik Indonesia. Jakarta

[5] Setyowati, Hanny; Hanifah, Hananun Zharfa dan Nugraheni, Rr Putri. 2013. Krim Kulit Buah Durian (Durio zibethinus L.) Sebagai Obat Herbal Pengobatan Infeksi Jamur Candida albicans. Strata 1 Farmasi, Sekolah Tinggi Ilmu Farmasi "Yayasan Pharmasi" Semarang.

[6] Jawetz, Melnick, Adelberg. 2005. Mikrobiologi Kedokteran. Edisi I: 352-358. Salemba Medika. Jakarta.
[7] Juwita, A.P.K., Yamlen, P.V.Y., Edy, H.J 2013. Formulasi Cream Ekstrak Etanol Daun Lamun (Syringodium isoetifolium). Program studi Farmasi FMIPA UNSRAT Manado. Jurnal Ilmiah Farmasi : Paracon.

[8] Garg, A., Aggarwal, D., Garg, S., and Sigla, A.K. 2002.Spreading of Semisolid Formulation:An Update Pharmaceutical Technology. September 2002 : 84- 102

[9] Miranti, L., 2009, Pengaruh Konsentrasi Minyak Atsiri Kencur (Kaemferia galangal) Dengan Basis Salep Larut Air terhadap Sifat Fisik Salep dan Daya Hambat Bakteri Staphylococcus aureus Secara In Vitro, Skripsi, Fakultas Farmasi Univeritas Muhammadiyah Surakrta, Surakarta.

[10] Radji, M., 2011, Buku Ajar Mikrobiologi Panduan Mahasiswa Farmasi dan Kedokteran, 68, 69, 99, 107, 201, 203-205, Jakarta, Penerbit Buku Kedokteran EGC.

[11] Rosalina, Dewi; Martodihardjo, Sunarko; Listiawan, Yulianto. 2010. Staphylococcus aureus sebagai Penyebab Tersering Infeksi Sekunder pada Semua Erosi Kulit Dermatosis Vesikobulosa. Departemen/Staf Medik Fungsional Kesehatan Kulit dan Kelamin Fakultas Kedokteran Universitas Airlangga. Surabaya. Berkala Ilmu Kesehatan Kulit \& Kelamin. Vol. 22 No. 2 Agustus 2010

[12] Sari, D.N.R., Susilo, D.K., 2017. Analisis Fitokimia Senyawa Antimikroba Pada Ekstrak Kulit Pisang Agung Semeru Dan Pisang Mas Kirana Varietas Lumajang. Jurnal : Bioma. Universitas Muhammadiyah Jember.Vo.2/No.2

[13] Susanti, Lina. 2006. Perbedaan Penggunaan Jenis Kulit Pisang Terhadap Kualitas Nata. Skripsi Sarjana Universitas Negeri Semarang. Semarang.

[14] Tranggono, R.I., Latifah, F. 2007. Buku Pegangan Ilmu Pengetahuan kosmetik. PT. Gramedia : Jakarta 